\title{
MODELLING THE TIMING OF LEAF UNFOLDING IN PEDUNCULATE OAK (Quercus robur L.) CLONAL SEED ORCHARD
}

\author{
MODELIRANJE VREMENA LISTANJA U KLONSKOJ SJEMENSKOJ \\ PLANTAŽI HRASTA LUŽNJAKA (Quercus robur L.)
}

\author{
Ivan ANDRIĆ ${ }^{1}$, Anamarija JAZBEC ${ }^{1}$, Valentino PINTAR ${ }^{1}$, Davorin KAJBA ${ }^{1}$
}

\begin{abstract}
Summary
For ten years, 53 genotypes of Pedunculate Oak were monitored in a clonal seed orchard. The aim of the study was to clarify effects of forcing and chilling temperature as background of leaf unfolding of pedunculate oak through the different kind of prediction models. The Pedunculate Oak is known to have three phenoforms of flushing phases, i.e., early, intermediate and late, and substantially different Growing Degree Days (GDD) requirements were found among these phenological groups. For each of the phenological groups, the GDD interval value required for leaf unfolding was determined, but the values varied between years, rendering the development of a simulation GDD model difficult. For these reasons, other variables - day of year, precipitation and insolation - were included in the assessment. The aim was to examine how these environmental factors determine the GDD requirement for leaf unfolding in the three Pedunculate Oak phenological groups. The results suggest that for all three flushing groups, insolation and the day of year are statistically significant predictors for GDD. Insolation was demonstrated to be the primary factor with the largest influence on the GDD values. In the early flushing group, insolation accounted for $74.1 \%$ of the variation, $90.6 \%$ in the intermediate group, and $78.7 \%$ in the late group. We recommend using the univariate GDD model for the early and intermediate flushing groups $\left(\mathrm{GDD}_{\text {early }}=-27.651+0.539 *\right.$ insolation; $\mathrm{GDD}_{\text {inter }}=$ $-48.084+0.690$ * insolation $)$ and the multivariate model for the late flushing group $\left(\mathrm{GDD}_{\text {late }}=-237.839+0.559\right.$ * insolation $+2.479 *$ day of year). To break the dormancy, chilling is required to be in the range of \pm 40 chilling units, and if the values are higher or lower, the trees require significantly higher forcing temperatures.
\end{abstract}

KEY WORDS: spring phenology, climate change, GDD, environmental drivers, chilling

\section{INTRODUCTION}

UVOD

The genus Quercus is widely distributed across large areas of the entire temperate region of the Northern Hemisphere. The European flora, as part of the European-West Asian formation centre, features 28 species of the genus Quercus, among which the Pedunculate Oak (Quercus robur L.) covers the largest areas. In Croatia, the Pedunculate Oak is the most valuable forest tree species and forms the largest continuous oak forest in Europe (the so-called Spačva basin in Eastern Slavonia). The tree's characteristics, such as the fineness, regularity and uniformity of annual rings, golden-yellow colour and durability, all combine to provide old Croatian oakwood with the internationally recognized technical name "Slavonian oak" (Klepac 2000). 
The Pedunculate Oak is an allogamous monoecious species, and the flowering and flushing are largely determined by climatic conditions. Distinct variations in the flushing of the Pedunculate Oak have been noted, and different authors have divided the species into different forms (Mátyás 1967, Stojković 1991) based on differing numbers of categories from very early flushing (super praecox) to very late flushing (tardissima). The late flushing form (Q. robur var. tardissima) develops leaves approximately five weeks later than the early form ( $Q$. robur var. praecox), and both forms occur in the all parts of the species' distribution. This phenomenon is most pronounced in the south-eastern part of the Pedunculate Oak range, where the early and late trees are easily distinguishable (Bacilieri et al.1994, Wesolowski andRowiński 2006, Perić et al. 2000). The late flushing types of Pedunculate Oak have a smaller length of crown, are more cylindrical with good straightness of the trunk and are less damaged by the late spring frost than the early types.

The genetic structure and variability of clonal phenoforms in clonal seed orchards were analysed, revealing that there were no significant differences in genetic differentiation among the phenoforms (Katičić et al. 2010). The analysed neutral markers were apparently not associated with adaptive differences between the phenoforms. The variation in flushing phenology is presumably one of the species' defensive strategies against late frosts. There are several reports of significant differences in genetic variability and differentiation among phenoforms within temperate tree species, e.g., late flushing forms of European beech had a higher intrapopulation genetic variability than early flushing forms. Oak trees were found to be more sensitive to temperatures with regard to leaf unfolding over an elevation gradient and were also found to have a lower chilling requirement for dormancy release than European beech (Chmura and Rožkowski 2002, Jazbec et al. 2007, Gömöry and Paule 2011, Dantec et al. 2014). Genetic variations in leaf unfolding timing between and within oak populations are likely due to differences in heat requirement rather than differences in chilling requirement (Dantec et al. 2014).

The technical quality of late flushing Pedunculate Oak trees is likely slightly better due to the delayed budburst and flushing of leaves, which is out of synchrony with eclosing caterpillars and avoids defoliation (Schütte 1957, Hunter 1992, Tikkanen and Julkunen-Tiltto 2003). In addition to the early and late types, there are also intermediate phenotypes, which are moving towards one or the other direction.

Because the late flushing Pedunculate Oak (Q. robur var. tardissima) is more desirable for cultivation in many European countries, the continued selection and collection of acorns from very late flushing trees from natural stands in the beginning of May is recommended. The establishment of clonal seed orchards with late flushing genotypes would certainly ensure higher quality forest reproductive material with the most advantageous genetic type.

The establishment of clonal seed orchards began with the goal of controlling more regular yield periodicity and obtaining seeds (acorns) with high genetic quality. The leaf unfolding of Pedunculate Oak is largely genetically controlled (Mátyás 1967, Stojković 1991, Baliuckas 2001), which provides an opportunity for legitimate selection of plus trees to achieve lasting phenological uniformity of leafing genotypes from which to establish clonal seed orchards. The phenology of trees is strongly driven by environmental factors, such as temperature, that have already altered the vegetative and reproductive phenology of many forest species. However, the impact of adverse weather conditions, such as heavy rainfall, high relative humidity, frost, low and high air temperatures, and hail, can sometimes disturb favourable phenological uniformity of phenophases in forest stands and within seed orchards (Wolgast 1972, Cecich 1997, Garcia-Mozo et al. 2001). Temperature and photoperiod are widely considered to be a major factors controlling the phenology of boreal and temperate tree species (Sarvas 1972, 1974, Heide 1993, Schwartz 2003, Chuine et al. 2003, 2010, Hänninen and Kramer 2007, Basler and Körner 2012, Fu et al. 2013).

Phenology is the study of the timing of life-history events that occur in a seasonal and repeated pattern. Understanding the processes responsible for macro-scale spatial and temporal phenological patterns is a critical step in developing predictive phenological models (Phillimore et al. 2013). While phenological responses may involve the integration of multiple environmental cues, the spring phenology of many plant species appears to be especially sensitive to temperature. The timing of leaf unfolding is mainly regulated by temperature in cold winter environments. Chilling temperatures break winter dormancy and subsequent warm temperatures induce leaf unfolding, which is why the phenological onset of spring correlates very well with the air temperature of the preceding months (Menzel 2002, Davi et al. 2011). Heat units, expressed in growing degreedays (GDD), are frequently used to describe the timing of biological processes. Approaches that use growing degreedays (GDD) assume a linear effect of temperature on the development rate via enzyme activity (Bonhomme 2000). In the areas of crop phenology and development, the concept of heat units, measured by GDD $\left({ }^{\circ} \mathrm{C}\right.$-day) has vastly improved the description and prediction of phenological events relative to other approaches, such as time of the year or day of year (McMaster and Wilhelm 1997). Growing degree days (GDD) models predict the day on which a phenological event should take place.

Phenological models, used to simulate leaf unfolding, i.e., the start of the growing season, are based on the response 
of bud growth to forcing temperatures and/or to chilling temperatures, and this response has been described with different types of mathematical functions (Chuine 2000). The leaf unfolding process is often considered to involve two stages (Cannell and Smith 1983, Hänninen 1990, Kramer 1994, Chuine 2000, Chuine et al. 2003). First, bud dormancy needs to be broken by exposure to cold temperatures during winter, referred to as chilling. Once sufficient chilling has accumulated, the bud enters the second phase of dormancy, during which sufficient warmth is needed to trigger bud burst, referred to as forcing. The accumulation of forcing is based on a linear temperature relationship above a given temperature threshold, and the interaction of chilling and forcing requirements with temperature determines the timing of leaf unfolding.

This work is based on ten years of data recording the leaf unfolding of Quercus robur $\mathrm{L}$. in a clonal seed orchard and meteorological data. The parameters are start time (day of year), base temperature, cumulative GDD, precipitation and insolation. From the start time, the daily temperatures above the base temperature are summed, and the model predicts that the phenological event will occur once the cumulative GDD requirement has been met. A number of approaches exist for identifying the best parameters under the GDD model, but most involve the iterative application of combinations of parameters to the temperature data and estimation of one of several related metrics that quantify the difference between the predicted and observed phenology (Bonhomme 2000). The aim of the study was to determine requirements of the GDD values, precipitation and insolation by each phenological group of pedunculate oak, as well as chilling requirements for breaking dormancy of vegetative buds and mutual relationship between chilling and GDD. Thus, the application of GDDs in the future could contribute to better and easier predictions of how phenoforms and pathogens are related, based on their biology and ecology. The values obtained by chilling could be used for the prediction of the required amount of forcing temperature and the occurrence of the leaf unfolding phase.

\section{MATERIALS AND METHODS} MATERIJALI I METODE

\section{Study Area - Područje istraživanja}

A clonal seed orchard of Pedunculate Oak (Quercus robur L.) was established in the spring of 2001 at the Forest Office Čazma in the lower Sava river provenance region of Croatia. The seed orchard has an area of 26 ha, contains 53 clones (genotypes) selected in seed stands, and features a total of 2,150 ramets (grafts) randomly planted in the orchard. The genotypes belong to a single seed region that includes seven subprovenances. The pruning and training systems of the grafts in the clonal seed orchard should produce a strong framework and good light penetration in the canopy (Kajba et al. 2008). An oval spindle training system is used after establishment, and the spacing between ramets is 10 $\times 8 \mathrm{~m}$. The total height of the training shape is up to seven meters with six scaffold whorls.

The clonal seed orchard is located at $45^{\circ} 45^{\prime} 55^{\prime \prime} \mathrm{N}$ and $16^{\circ}$ $35^{\prime} 32^{\prime \prime} \mathrm{E}$ in the northwest part of Croatia. The climate in this region is moderately warm and rainy with a two short dry period (April and July). The average value of coldest month temperature is between $-3^{\circ} \mathrm{C}$ and $18^{\circ} \mathrm{C}$, while the mean temperature of the warmest month is not above 22 ${ }^{\circ} \mathrm{C}$. The mean annual temperature is $9.8^{\circ} \mathrm{C}$, and the mean annual precipitation of $810 \mathrm{~mm}$ is evenly distributed throughout the year.

\section{Phenology measurements - Fenološka motrenja}

During the 10-year study period (2004-2013), the phenological data of leaf unfolding and meteorological records were studied. Only well-developed individuals (grafts) were chosen for observation. The start date of the leaf unfolding stage is defined as the point at which the entire leaf blade and leaf stalk were visible.

Each year, observation began before any buds began to break, and observation was made every 10 days until the $10^{\text {th }}$ of May. The meteorological data were supplied by the Croatian Meteorological and Hydrological Service, based on data recorded at the Čazma meteorological station, which is located $1 \mathrm{~km}$ from the orchard site (DHMZ). Observations were made on ramets of 53 clones randomly selected across the entire area of the orchard. The start of heat accumulation has been taken from the $1^{\text {st }}$ of January. Only positive values of GDD were taken into account to calculate cumulative sums. Insolation is expressed in hours (h) and precipitation in $\mathrm{mm}$. The ten years of leaf unfolding data and the corresponding weather data were used to build the phenology models.

\section{Statistical analysis - Statistička analiza}

Growing Degree Days (GDD) were calculated using the Hand Calculating Degree Days method described by Snyder (1985):

$$
G D D=\frac{T_{\max }+T_{\min }}{2}-T_{\text {base }}
$$

$$
\begin{aligned}
& \text { If: }\left[\frac{T_{\max }-T_{\min }}{2}\right]-T_{\text {base }}>0 \begin{array}{l}
\text { GDD from the days included in } \\
\text { final sums; }
\end{array} \\
& \text { If: }\left[\frac{T_{\max }-T_{\min }}{2}\right]-T_{\text {base }}<0 \begin{array}{l}
\text { GDD from the days not included } \\
\text { in final sums. }
\end{array}
\end{aligned}
$$

Here, $\mathrm{T}_{\max }$ and $\mathrm{T}_{\min }$ are daily maximum and minimum air temperatures, respectively, and $\mathrm{T}_{\text {base }}$ is the base temperature. 
The temperature base was $5{ }^{\circ} \mathrm{C}$, which has been used for other forest tree species as it is presented in formula 1 (Cannel and Smith 1983, Chassagneux and Choisnel 1986, Kasprzyk 2009, Dobrowolska et al. 2011).

Descriptive statistics were calculated for all analysed variables, and the level of statistical significance was set at $5 \%$. To classify clones by GDD for the study period (2004-2013), we used a k-means clustering that divided all 53 investigated clones into three groups depending on the leaf unfolding (early, intermediate and late flushing groups). By using repeated measures analysis of variance, we tested whether and how other analysed variables (precipitation, day of year, and insolation) differ between the GDD clusters. Our model contains three parameters - effect of GDD groups (between subject) the effect of years, and the interaction years $\times$ GDD groups (within subject) - because we wanted to test whether our analysed variables (according to GDD groups) behaved approximately the same throughout the analysed period (Davis 2002). For testing sphericity we use Mauchly`s Sphericity test and if sphericity assumption has be violated we use Greenhouse-Geisser Epsilon (G-G) and Huynh-Feldt-Lecoutre epsilon (H-F-L) correction factors which adjust the univariate test degrees of freedom for within subject testing. To determine which of the analysed variables best describes GDD for each GDD group, we used a regression analysis regardless of the clones and the year. First, an univariate regression was performed for each analysed variable. Then, we performed a multivariable (multiple) regression for variables that were statistically significant in the univariate models. Finally, we choose the most appropriate model that served as the best predictor for GDD using differences in $\mathrm{R}^{2}$ values as the selection criterion (Sokal and Rohlf 1995).

The chilling accumulation calculations were based on thetemperature difference between $\mathrm{T}_{\min }$ and $\mathrm{T}_{\max }$ in the period between $1^{\text {st }}$ November and $28^{\text {th }}$ February (formula 2), with $\leq 5^{\circ} \mathrm{C}$ adapted from the Thermal Time model (Cannell and Smith, 1983). All statistical analyses were conducted using Statistica 11.0 (StatSoft Inc. 2013).

$$
\begin{aligned}
& \text { Chilling(SUM } x \text { ) } \\
& =\sum_{\text {startdate }}^{\text {enddate }}\left(\begin{array}{lr}
0 & T_{\text {min }}=T_{\text {base }} \\
x & {\left[T_{\text {base }}-T_{\text {min }}\right]} \\
x & {\left[T_{\text {max }}-T_{\text {min }}\right]\left(\begin{array}{rl}
\left(f T_{\text {max }}<T_{\text {base }}\right) \\
0 & T_{\text {min }}>T_{\text {base }}
\end{array}\right)}
\end{array}\right.
\end{aligned}
$$

- If the $T_{\min }$ is equal to the $T_{\text {base }}$ then the chilling value for that day is 0 .

- $X$ represents an interval in degrees between the $T_{\min }$ and the $T_{\text {base }}$ or between $T_{\min }$ and $T_{\max }$ if $T_{\max }$ is less than the $T_{\text {base }}$

- If the $T_{\text {min }}$ is higher than the $T_{\text {base }}$ value then chilling for that day is 0 .

\section{RESULTS}

\section{REZULTATI}

The averaged data are clearly segregated between the three groups of Q. robur phenoforms (early flushing, intermediate and late flushing) for all measured parameters during the duration of the experiment, as shown in Table 1. The start date of leaf unfolding phenoform is clearly defined by the GDD model (Table 1 and Figure 1).

The mean values of GDD were 118.42 for the early flushing group, 188.34 for the intermediate group and 261.61 for the late group of oak clones. All other measured parameters (precipitation, day of year, and insolation) are similarly separated and are divided into three separate groups (Figure 2). For the early flushing group, the mean day of year is 85 and insolation is 271.04 hours, which achieved the GDD requirements and the clones of that group started with the leaf unfolding. The intermediate group required an average of 98 days and 342.49 hours of insolation, whereas the late flushing group required 109 days and 411.57 hours of insolation. The calculated Coefficient of Variation (C.V. \%) values for all parameters are lowest for the late flushing form group, likely because they belong to a group with at least of 9 genotypes. In contrast, the intermediate group contains 13 of genotypes, and the early group contains 31 genotypes.

The results of k-means clustering of the clones according to their values of GDD for the period of 2004-2013 are shown in Fig. 1. The clones are clearly classified into three groups (early, intermediate and late flushing).

To examine how the other analysed variables (precipitation, day of year, and insolation) affected the GDD groups, the variables were tested with repeated measures ANOVA to determine whether they individually participate in the GDD groups, their behaviour over years and their behaviour over years under certain clusters. Because sphericity assumption has been violated we use G-G and the H-F-L correction factors. In Table 2 we gave adjusted $\mathrm{p}$ value for both. In all tests the $\mathrm{p}$ value before and after using correction factors $p$ values were the same $(p<0.0001)$. Sphericity test, G-G episolon and H-F-L epsilon for Precipitation (Chi2=514.61; $d f=44 ; p<0.001 ; G-G=0.3337 ; H-F-$ $L=0.3574$ ); Insolation (Chi2=348.74, $d f=44 ; p<0.001$; $G-G=0.4446 ; H-F-L=0.4881)$ and day of year $(C h i 2=313.64$ $d f=44 ; p<0.001 ; G-G=0.3994$; H-F-L $=0.4341$ ).

The results of the repeated measures ANOVA (Table 2) show that there are statistically significant differences between each group for all of the analysed variables. There is a statistically significant difference over the years and significant differences in the interaction between the GDD group and the years, which means that all the analysed variables for individual GDD group over the year do not behave the same (Figure 2). 
Table 1: Descriptive data for the seasonal GDD and the other parameters (precipitation, insolation and day of year) according to flushing groups ( $E$ - early, I - intermediate, L - late)

Tablica 1: Deskriptivna statistika za GDD i ostale parametre (oborine, insolacija i broj dana) s obzirom na forme listanja (E - rani, I - srednji, L - kasni).

\begin{tabular}{|c|c|c|c|c|c|c|c|c|c|c|c|c|}
\hline \multirow{3}{*}{$\begin{array}{l}\text { Year } \\
\text { Godina }\end{array}$} & & & & \multicolumn{9}{|c|}{$\begin{array}{l}\text { Parameters (accumulated from the } 1^{\text {st January) }} \\
\text { Parametri (početak zbrajanja od 1. siječnja) }\end{array}$} \\
\hline & \multicolumn{3}{|c|}{ GDD } & \multicolumn{3}{|c|}{$\begin{array}{l}\text { Precipitation }(\mathrm{mm}) \\
\text { Oborine }(\mathrm{mm})\end{array}$} & \multicolumn{3}{|c|}{$\begin{array}{l}\text { Day of year } \\
\text { Br. dana }\end{array}$} & \multicolumn{3}{|c|}{$\begin{array}{l}\text { Insolation (h) } \\
\text { Insolacija }(h)\end{array}$} \\
\hline & $\mathrm{E}$ & I & $L$ & $\mathrm{E}$ & I & $\mathrm{L}$ & $\mathrm{E}$ & I & $\mathrm{L}$ & $\mathrm{E}$ & I & $\mathrm{L}$ \\
\hline 2004 & 118.38 & 198.93 & 268.45 & 171.02 & 248.82 & 276.33 & 94 & 107 & 116 & 299.37 & 345.98 & 393.51 \\
\hline 2005 & 138.15 & 237.67 & 255.85 & 169.63 & 210.25 & 210.41 & 95 & 111 & 113 & 355.73 & 446.54 & 468.18 \\
\hline 2006 & 104.19 & 196.51 & 258.97 & 97.83 & 125.30 & 144.28 & 91 & 105 & 113 & 255.67 & 341.12 & 389.30 \\
\hline 2007 & 217.59 & 306.42 & 391.73 & 160.83 & 187.91 & 189.48 & 81 & 99 & 109 & 333.62 & 455.55 & 556.51 \\
\hline 2008 & 127.98 & 176.68 & 214.84 & 66.60 & 100.78 & 114.41 & 79 & 92 & 100 & 286.72 & 356.25 & 403.67 \\
\hline 2009 & 81.91 & 94.83 & 276.79 & 113.41 & 117.56 & 129.91 & 77 & 83 & 107 & 194.92 & 220.65 & 377.40 \\
\hline 2010 & 66.86 & 92.14 & 201.57 & 175.85 & 184.53 & 230.91 & 77 & 83 & 102 & 155.43 & 184.65 & 296.50 \\
\hline 2011 & 72.13 & 127.52 & 248.51 & 27.18 & 33.28 & 45.57 & 72 & 83 & 102 & 184.62 & 248.23 & 373.48 \\
\hline 2012 & 174.58 & 290.57 & 291.24 & 80.73 & 88.85 & 88.60 & 91 & 110 & 110 & 440.28 & 539.09 & 534.12 \\
\hline 2013 & 82.45 & 162.16 & 208.18 & 368.07 & 383.72 & 385.70 & 99 & 109 & 113 & 204.04 & 286.82 & 323.07 \\
\hline Average - Srednja vrijednost & 118.42 & 188.34 & 261.61 & 143.12 & 168.10 & 181.56 & 85 & 98 & 109 & 271.04 & 342.49 & 411.57 \\
\hline $\begin{array}{l}\text { Minimum - Minimalna } \\
\text { vrijednost }\end{array}$ & 66.86 & 92.14 & 201.57 & 27.18 & 33.28 & 45.57 & 72 & 83 & 100 & 155.43 & 184.65 & 296.50 \\
\hline $\begin{array}{l}\text { Maximum - Maksimalna } \\
\text { vrijednost }\end{array}$ & 217.59 & 306.42 & 391.73 & 368.07 & 383.72 & 385.70 & 99 & 111 & 116 & 440.28 & 539.09 & 556.51 \\
\hline Range - Opseg & 150.73 & 214.28 & 190.16 & 340.89 & 350.44 & 340.13 & 27 & 28 & 17 & 284.85 & 354.44 & 260.01 \\
\hline $\begin{array}{l}\text { Standard deviation - } \\
\text { Standardna devijacija }\end{array}$ & 48.42 & 74.18 & 54.72 & 94.04 & 99.34 & 99.83 & 10 & 12 & 6 & 89.53 & 112.65 & 84.20 \\
\hline C.V. \% - Koeficijent varijacije (\%) & 40.89 & 39.39 & 20.92 & 65.71 & 59.10 & 54.98 & 11.14 & 12.28 & 5.26 & 33.03 & 32.89 & 20.46 \\
\hline
\end{tabular}

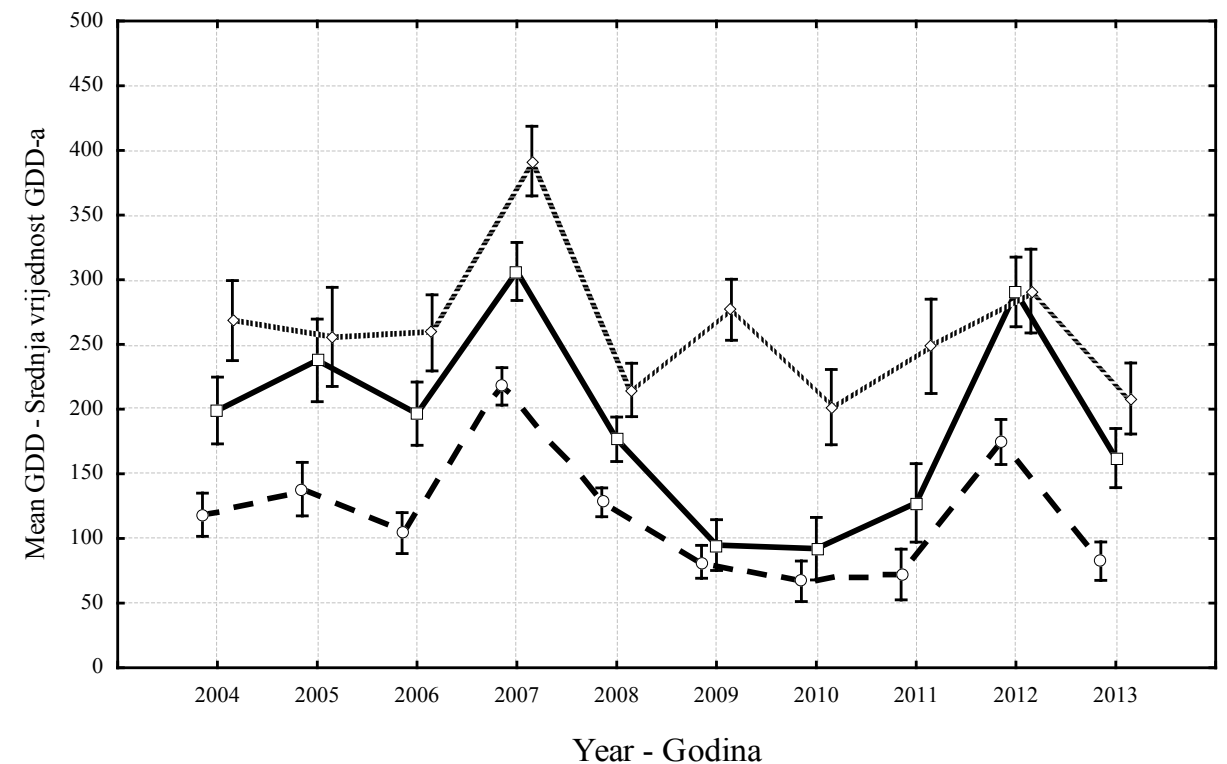

GDD early - GDD rana
GDD intermediate - GDD srednja
GDD late - GDD kasna

Figure 1: Three phenological groups of Quercus robur separated by GDD values (early, intermediate and late flushing groups)

Slika 1: Tri fenološke forme hrasta lužnjaka prikazane prema GDD vrijednostima (rane, srednje i kasno listajuće forme) 

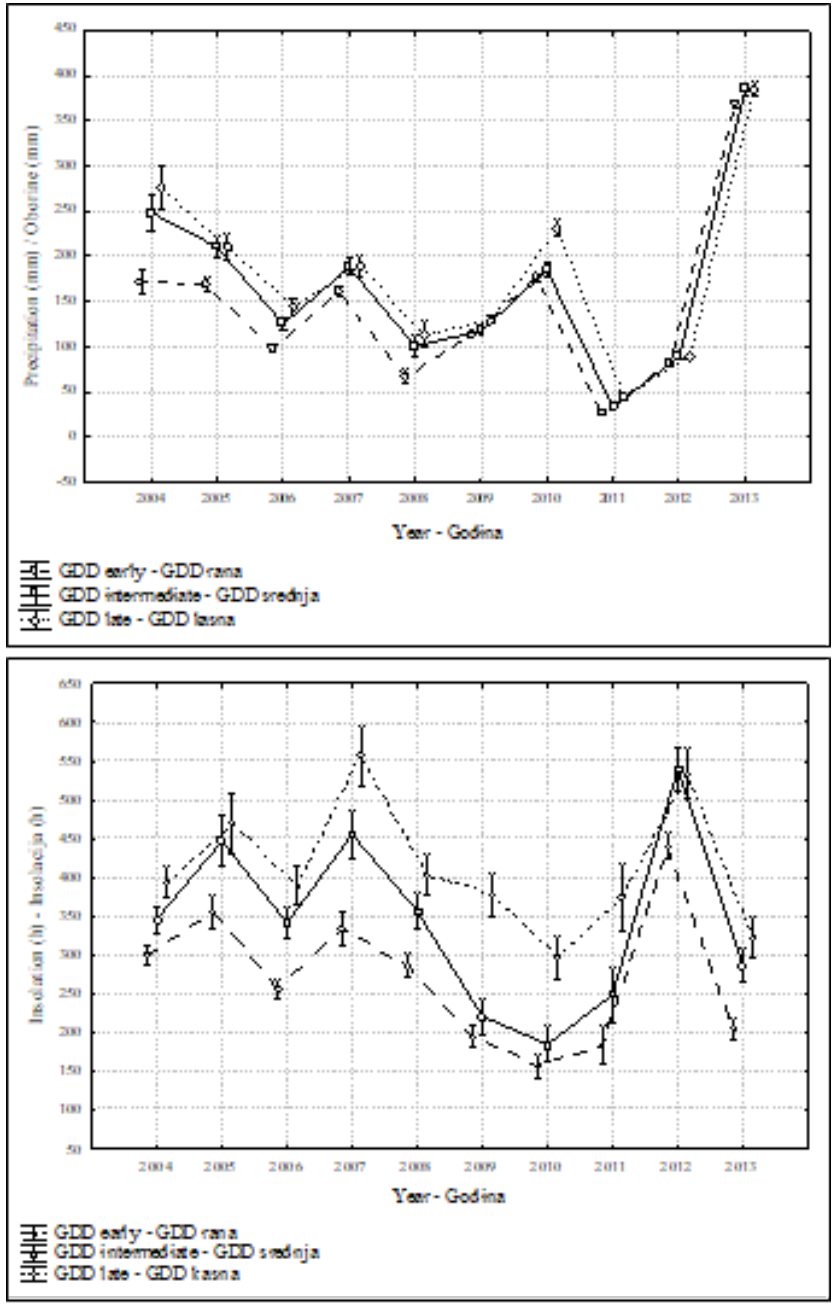

The results of the regression analysis are shown in Table 3. The goal was to identify the best linear model for prediction of the GDD values for each of the GDD groups. First, univariate linear regressions were calculated for all of the analysed variables (GDD was the dependent variable; Table 2). From the results for all three groups, insolation and day of year are clearly statistically significant predictors for GDD. Although these factors are significant predictors,

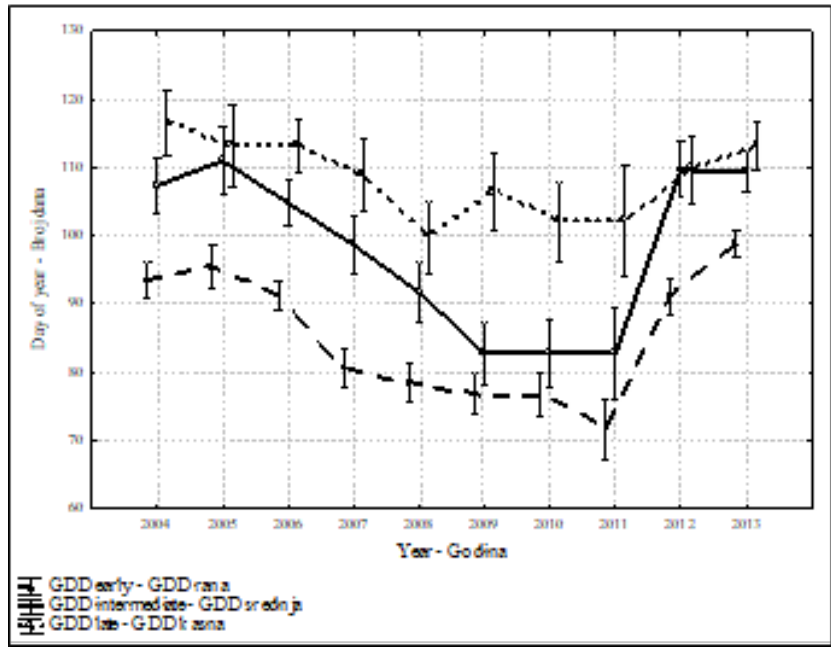

Figure 2:Variations in parameters (precipitation, insolation and day of year) according to flushing groups. Error bars are $95 \%$ confidence interval

Slika 2: Varijacije parametara (oborine, insolacija i broj dana) s obzirom na forme listanja. Vjerojatnost pogreške je u intervalu pouzdanosti $95 \%$

their coefficients of determination range from $71 \%$ to 89 $\%$ for insolation and from $26 \%$ to $62 \%$ for the day of year. In addition to the univariate models, we created a multivariate model for the variables were shown to be statistically significant in the univariate models, i.e., insolation and day of year.

When we include the value of the day of year to the insolation value for the early flushing group of Pedunculate Oak,

Table 2. Results of the repeated measures ANOVAfor GDD flushing groups Tablica 2. ANOVA s ponovljenim mjerenjima za GDD fenološke grupe

\begin{tabular}{|c|c|c|c|c|c|c|c|}
\hline \multirow[b]{2}{*}{$\begin{array}{l}\text { Source of variability } \\
\text { Izvor varijabilnosti }\end{array}$} & \multicolumn{3}{|c|}{$\begin{array}{c}\text { Precipitation }(\mathrm{mm}) \\
\text { Oborine }(\mathrm{mm})\end{array}$} & \multicolumn{2}{|c|}{$\begin{array}{l}\text { Insolation (h) } \\
\text { Insolacija (h) }\end{array}$} & \multicolumn{2}{|c|}{$\begin{array}{c}\text { Day of year } \\
\text { Broj dana } \\
\end{array}$} \\
\hline & df & $\mathrm{F}$ & $\mathrm{p}$ & $\mathrm{F}$ & $\mathrm{p}$ & $\mathrm{F}$ & $\mathrm{p}$ \\
\hline GDD group - GDD grupa & 2 & 123.47 & $<0.0001$ & 146.89 & $<0.0001$ & 131.17 & $<0.0001$ \\
\hline Error - Pogreška & 50 & & & & & & \\
\hline Years-Godine & 9 & 1280.22 & $<0.0001^{*}$ & 186.49 & $<0.0001^{*}$ & 55.53 & $<0.0001 *$ \\
\hline Years ${ }^{*} \mathrm{GDD}$ group - Godine ${ }^{*} G D D$ grupa & 18 & 14.3 & $<0.0001^{*}$ & 6.08 & $<0.0001^{*}$ & 3.8 & $<0.0001^{*}$ \\
\hline Error-Pogreška & 450 & & & & & & \\
\hline
\end{tabular}

Note:* Adjusted $\mathrm{p}$ values for G-G and H-F-L correction

Napomena:* Podešene $p$ vrijednosti za G-G i H-F-L korekciju 
the total value of GDD does not change, remaining $R^{2}=74.1$ $\%$. The day of year is not a statistically significant variable in combination with the insolation. Therefore, for the early flushing form of Pedunculate Oak, we recommend the univariate model that features only the insolation as an independent variable: $G D D_{\text {early }}=-27.651+0.539 *$ insolation.

For the intermediate flushing group, both variables (insolation and day of year) were statistically significant, and the total variability of GDD with this model is $R^{2}=90.6 \%$. Based on the univariate model for insolation, $R^{2}=89.1 \%$, which is a difference of only $1.5 \%$. Therefore, we conclude that the recommended model contains only the insolation variable: $G D D_{\text {inter }}=-48.084+0.690$ * insolation.

For the late flushing group, both variables (insolation and day of year) were statistically significant, with a total explained GDD variability of $R^{2}=78.7 \%$. The $R^{2}$ value for the univariate model for insolation is $70.8 \%$. Due to the $R^{2}$ difference of $7.9 \%$, we recommend the use of the multivariate model containing the both variables (insolation and day of year): $G D D_{\text {late }}=-237.839+0.559 *$ insolation +2.479 * day of year.

A second-degree polynomial has proven to be the best model of the relationship between chilling and GDD $(F(3,7)$ $=25.71, p<0.001)$, which indicates that if the chilling is approximately zero, the GDD group needs fewer forcing temperatures, and if the chilling units are above or below the value of \pm 40 units, then GDD group requires much more accumulated forcing (Figure 3). Although the parabola is shifted from the centre, the x parameter (0.1644) shows that this shift is not statistically significant $(t=0.54$, $p=0.60)$. In contrast, the parameter of the quadratic term $(0.012)$ is significant at the significance level of $9.6 \%(t$ $=1.92, p=0.096$ ). Additionally, to break the dormancy, chilling is required to bein the range of \pm 40 chilling units, and if the value is higher or lower than this number, the trees require significantly higher forcing temperatures.

\section{DISCUSSION AND CONCLUSIONS RASPRAVA I ZAKLJUČCI}

Earlier investigations of Pedunculate Oak noticed the existence of different phenological forms that varied from early flushing (var. praecox) to late flushing (var. tardissima), leading to variations in the leaf unfolding between $1^{\text {st }}$ March and $10^{\text {th }}$ May (Mátyás 1967, Stojković 1991, Perić et al. 2000, Baliuckas et al. 2001, Wesolowski and Rowiński 2006). In this study, the phenoforms were properly separated into three groups - early, intermediate and late flushing types based on GDD and three other variables (Table 1, Figure

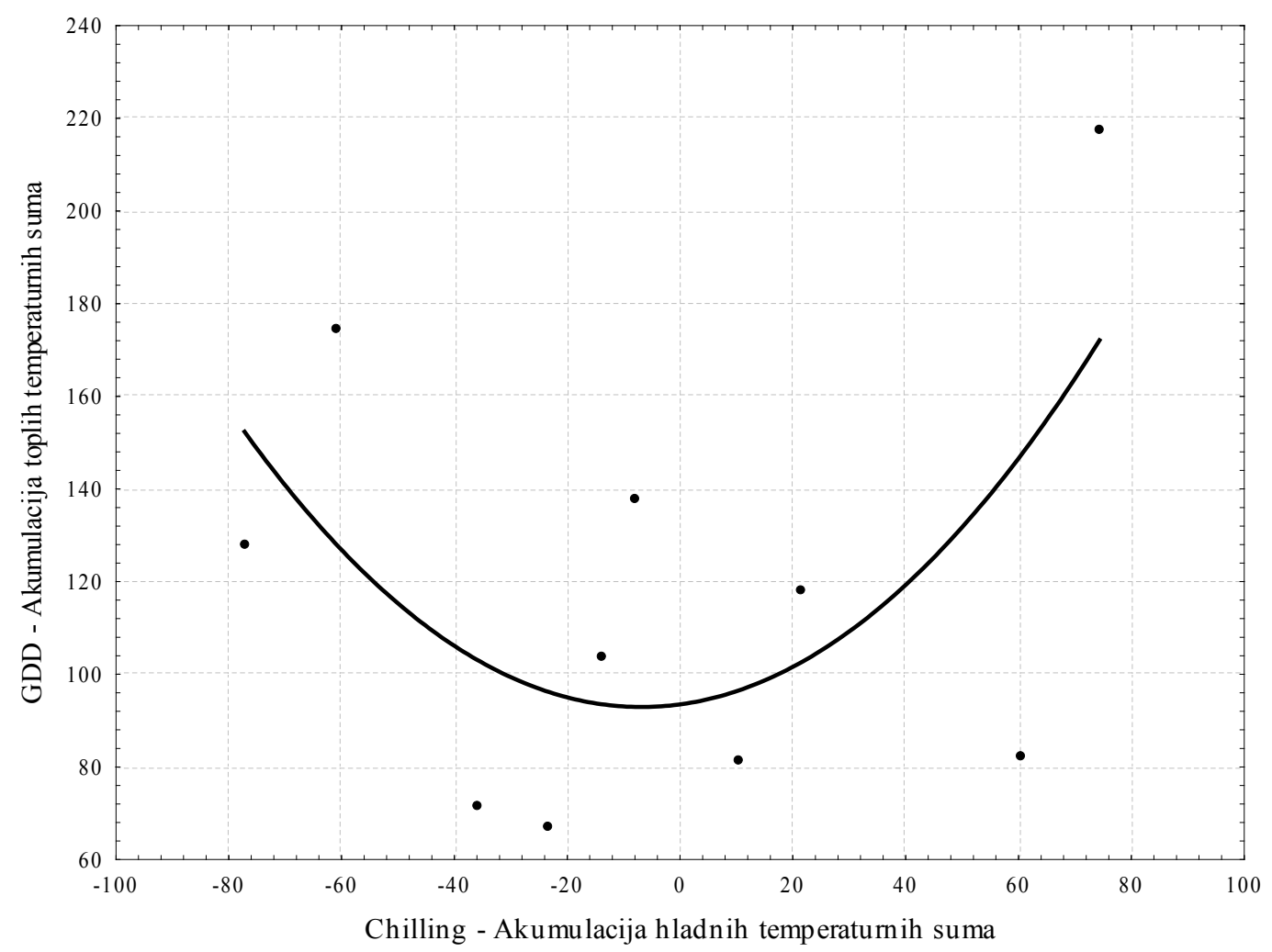

Figure 3: Relationship between the chilling accumulation (chilling units between $1^{\text {st }}$ November and $28^{\text {th }}$ February) and forcing accumulation (accumulated growing degree days between $1^{\text {st }}$ January and $10^{\text {th }}$ May)

Slika 3: Odnos između akumulacije inaktivnih temperatura (hladne temperaturne vrijednosti između 1. studenog i 28. veljače) i proljetnih temperatura (akumulacija toplih temperaturnih vrijednosti između 1. sječnja i 10. svibnja) 
Table 3. Results of the regression analysis in which GDD is the dependent variable for each GDD flushinggroup Tablica 3. Rezultat regresijske analize u kojima je GDD zavisna varijabla za svaku GDD fenološku grupu

\begin{tabular}{|c|c|c|c|c|c|c|c|c|c|c|c|}
\hline \multirow{3}{*}{ GDD } & \multicolumn{6}{|c|}{$\begin{array}{l}\text { Univariate model } \\
\text { Univarijatni model } \\
\end{array}$} & \multicolumn{5}{|c|}{$\begin{array}{l}\text { Multivariable model } \\
\text { Multivarijatni model }\end{array}$} \\
\hline & Variable & Intercept & & & & & Variable & & & & $\mathrm{R}^{2}$ \\
\hline & Varijabla & $\begin{array}{l}\text { Slobodan } \\
\text { član modela }\end{array}$ & PE & SE & $\mathrm{p}$ & $\mathrm{R}^{2}$ & Varijabla & PE & SE & $\mathrm{p}$ & RMSE \\
\hline \multirow{6}{*}{$\begin{array}{l}\text { Early } \\
\text { Rani }\end{array}$} & & & & & & & Intercept & & & & \\
\hline & & & & & & & $\begin{array}{l}\text { Slobodan član } \\
\text { modela }\end{array}$ & -25.853 & 12.815 & 0.045 & 0.741 \\
\hline & $\begin{array}{l}\text { Precipitation } \\
\text { Oborine }\end{array}$ & 118.124 & 0.002 & 0.030 & 0.956 & 0.000 & & & & & 30.843 \\
\hline & $\begin{array}{l}\text { Insolation } \\
\text { Insolacija }\end{array}$ & -27.651 & 0.539 & 0.018 & $<0.001$ & 0.741 & $\begin{array}{l}\text { Insolation } \\
\text { Insolacija }\end{array}$ & 0.541 & 0.023 & $<0.001$ & \\
\hline & $\begin{array}{l}\text { Day of year } \\
\text { Broj dana }\end{array}$ & -100.718 & 2.260 & 0.240 & $<0.001$ & 0.269 & $\begin{array}{l}\text { Day of year } \\
\text { Broj dana }\end{array}$ & -0.028 & 0.181 & 0.878 & \\
\hline & & & & & & & $\begin{array}{l}\text { Intercept } \\
\text { Slobodan član } \\
\text { modela }\end{array}$ & -114.919 & & $<0.001$ & 0.906 \\
\hline \multirow{5}{*}{$\begin{array}{l}\text { Inter- } \\
\text { mediate } \\
\text { Srednji }\end{array}$} & $\begin{array}{l}\text { Precipitation } \\
\text { Oborine }\end{array}$ & 169.427 & 0.112 & 0.080 & 0.155 & 0.015 & & & & & 27.351 \\
\hline & $\begin{array}{l}\text { Insolation } \\
\text { Insolacija }\end{array}$ & -48.084 & 0.690 & 0.020 & $<0.001$ & 0.891 & $\begin{array}{l}\text { Insolation } \\
\text { Insolacija }\end{array}$ & 0.597 & 0.031 & $<0.001$ & \\
\hline & $\begin{array}{l}\text { Day of year } \\
\text { Broj dana }\end{array}$ & -277.821 & 4.751 & 0.327 & $<0.001$ & 0.622 & $\begin{array}{l}\text { Day of year } \\
\text { Broj dana }\end{array}$ & 1.006 & 0.257 & $<0.001$ & \\
\hline & & & & & & & Intercept & & & & \\
\hline & & & & & & & $\begin{array}{l}\text { Slobodan član } \\
\text { modela }\end{array}$ & -237.839 & 40.045 & $<0.001$ & 0.787 \\
\hline \multirow{3}{*}{$\begin{array}{l}\text { Late } \\
\text { Kasni }\end{array}$} & $\begin{array}{l}\text { Precipitation } \\
\text { Oborine }\end{array}$ & 274.204 & -0.069 & 0.077 & 0.375 & 0.009 & & & & & 34.063 \\
\hline & $\begin{array}{l}\text { Insolation } \\
\text { Insolacija }\end{array}$ & -9.618 & 0.659 & 0.045 & $<0.001$ & 0.708 & $\begin{array}{l}\text { Insolation } \\
\text { Insolacija }\end{array}$ & 0.559 & 0.045 & $<0.001$ & \\
\hline & $\begin{array}{l}\text { Day of year } \\
\text { Broj dana }\end{array}$ & -311.111 & 5.278 & 0.744 & $<0.001$ & 0.364 & $\begin{array}{l}\text { Day of year } \\
\text { Broj dana }\end{array}$ & 2.479 & 0.500 & $<0.001$ & \\
\hline
\end{tabular}

1). Furthermore, the sum of temperature could interact with the other environmental variables.

Statistically significant differences were obtained for all variables (GDD, precipitation, day of year and insolation) and for variable differences between years over the course of the study period. The results are consistent with the observations of significant leaf unfolding variability between years (Morin et al. 2010). The experimental warming and reduced precipitation for several populations of three European oak species (Quercus robur, Q. pubescens, Q. ilex) in this study caused a longer growing season and higher mortality. The leaf unfolding date was not significantly affected by variations in water quantity, but the date varied significantly by year. Certain genotypes may respond to a higher amount of precipitation, which ultimately means that they need a longer time and many more hours of insolation to facilitate leaf unfolding.

Temperature, which is the prime environmental factor regulating the leaf unfolding process, in addition to other environmental cues, such as photoperiod, may modulate the leaf unfolding process, especially for the late flushing species (Basler and Körner 2012, Caffarra et al. 2011, Heide 1993, Körner and Basler 2010). Several experiments have tested the effects of increasing temperature, and the leaf unfolding date was often advanced by higher temperatures (Repo at al. 1996, Guak et al. 1998, Arft et al. 1999, Hollister et al. 2005, Kilpelainen et al. 2006, Cannel et al. 1999, Menzel et al. 2001). Certain results confirm that continued and intense warming may not result in further advances in the date of leaf unfolding in the late successional species of oak and beech if the warming exceeds a certain threshold that leads to insufficient chilling temperatures for dormancy release (Fu et al. 2012b, 2013). The leaf unfolding of sessile oaks was 2.3 times more sensitive to temperatures over an elevation gradient than that of beech trees (Dantec et al. 2014). The timing of leaf unfolding in deciduous forest trees is genetically determined with respect to temperature changes (Derory et al. 2006, Vitasse et al. 2010), and temperature requirements are under strong genetic control (Rousi and Pusenius 2005, Sanz-Perez et al. 2009). The leaf unfolding date has been shown to be strongly genetically controlled 
in several species (Worral 1983, Billington and Pelham 1991, von Wuehlisch et al. 1995). The leaf unfolding dates of three species (birch, oak and beech) have been shown to advance significantly with warming in two experimental years (Fu et al. 2013). An earlier correlative study revealed that Q. Robur flushing in the UK had advanced and that temperatures in the February to April time window were strongly negatively correlated with the first leaf unfolding date (Sparks and Carey, 1995). Altitudinal transplant experiments of $Q$. petraea, a close relative of $Q$. robur, have revealed high levels of temperature-mediated plasticity. For example, a $1{ }^{\circ} \mathrm{C}$ rise in mean spring temperature caused leaf unfolding to advance by approximately six (Vitasse et al. 2010) to seven days (Phillimore et al. 2013).

A phenological model for Quercus petraea was formulated to predict the date of budburst and the increase in leaf area as a function of cumulative temperature and of day-length. Budburst occurs when the temperature sum of the past 10 days exceeds a given threshold, which is a decreasing function of day-length (Nizinski and Saugier 1988).

Accumulated GDD is often assumed to be effective for predicting leaf unfolding in trees in present climate conditions (Chuine et al. 2000, Chuine and Beaubien 2001). In this research on the influence of variables, such as precipitation, day of year and insolation, on GDD values, insolation is found to be the main factor that best determined the real value of GDD. Insolation predicted the GDD value with an accuracy of 74.1 to $89.1 \%$ (Figure 2). Other parameters do not have as strong an impact on GDD, and only day of year variable contributed significantly, with the values of $1.5 \%$ (for intermediate) and $7.9 \%$ for the late flushing group. Therefore, separate prediction GDD models are used for each of the leaf unfolding groups. Further research should perhaps examine the possibility of using only the insolation as the main variable in the estimation of GDD. The leaf unfolding process is very sensitive to environmental drivers, including both temperature and photoperiod (Basler and Körner 2012, Heide 1993). Comparing the performance of two methods (time-window and GDD) in the prediction of the spatiotemporal variation in the timing of first flushing will provide congruent insights into the cues and processes that underpin geographic variation in the phenology of Quercus robur (Phillimore et al. 2013).

As a part of this investigation, we decided to apply the GDD method to facilitate future predictions for the leaf unfolding. Natural stands and clonal seed orchards are in constant environmental struggle with various pathogens that to some extent undermine their stability. Thus, the application of GDDs could in the future contribute to better and easier predictions of how phenoforms and pathogens are related, based on their biology and ecology. Late leaf flushing among Pedunculate Oaks serves as an antiherbivore defence, via the development of leaves that is asynchronous with the eclosion of caterpillars. This trait avoids the costs of defoliation, which may provide benefits later in the growing season (Hunter 1992, Wesolowski and Rowiński 2006). Large intraspecific variation in the timing of budburst of the $Q u$ ercus robur may have a negative effect on herbivores, such as Operophtera brumata (Tikannen and Julkunen-Tiltto 2003). Late flushing forms are not harmed by late spring frost, which may result in lower damage and better quality trees. The main goal of the testing of the GDD model in this example of oak phenology is to determine the average values of the studied parameters associated with GDD that are required by each phenological group, specifically for the leaf unfolding trait.

The duration of the growing season may increase the vegetation period. Due to climate change, this duration is an important feature for carbon sequestration (Delpiere et al. 2009) and to the growth response (Kramer et al. 2000). Several studies have documented advances in the leaf unfolding and flowering dates of 2 to 3 days per decade on average during the last 64 years (Menzel 2000). Certain experimental results showed that future warming should continue to advance the tree species leaf unfolding dates, but other results also suggest that the phenological response of three European oak species to increased temperatures is nonlinear and can vary strongly among species (Morin et al. 2010).

A negative relationship is known to exist between required chilling and forcing, and Murray et al. (1989) reported that a negative exponential equation was the best fit across all fifteen investigated woody species. The findings of Fu et al. (2013) suggest that a constant forcing requirement could be used to predict the timing of leaf unfolding in oaks only when the chilling requirement is either far too low or fully reached. In between, a linear (negative) relationship between chilling and forcing needs to be applied. The relationship between GDD and chilling units (CU) was sigmoidal; GDD was not correlated with CU both at very low (< $40 \mathrm{CU}$ ) and very large ( $>80 \mathrm{CU})$ chilling unit values. When chilling was less than $40 \mathrm{CU}$, the forcing requirement of oaks no longer increased and even appeared to become uncoupled from the accumulated chilling units. The breakdown of the negative linear relationship between forcing requirement and chilling at very low chilling units may be related to the influence of photoperiod. A long photoperiod may partially compensate for a lack of sufficient chilling (Caffarra et al. 2011, Garber 1983, Nienstaedi 1966, Wareing 1953). The values obtained by chilling could be used for the prediction of the required amount of forcing temperature and the occurrence of the leaf unfolding phase, which may indicate accurate protection from pests/diseases in clonal seed orchards or in natural stands of Pedunculate Oak. 
For each of the phenoform groups (early, intermediate and late flushing groups), an appropriate model for the prediction of the unfolding trait is specified and selected. The timing of leaf unfolding is also an important characteristic related to pests and insects and to the occurrence of the late spring frost. The models based the observations obtained over ten years should be applied to other clonal seed orchards and natural stands of Pedunculate Oak to verify their universality and to maintain their constancy and applicability.

\section{ACKNOWLEDGMENTS ZAHVALE}

This work was supported by Croatian Science Foundation through the research project FRAXINPRO [IP-11-2013].

The authors gratefully acknowledge Dr. Francois Lefèvre and Dr. Yongshuo H. Fu for constructive comments. Special thanks to Marina Antulov, MSc and Bernarda Bukovac, MSc for their kind support in collecting of data in seed orchard.

\section{REFERENCES}

\section{LITERATURA}

- Arft, A.M., M.D. Walker, J. Gurevitch, J.M. Alatalo, M.S. BretHarte, M. Dale et al., 1999: Responses of tundra plants to experimental warming: meta-analysis of the international tundra experiment, Ecological Monographs, 69: 491-511.

- Bacilieri, B.R., A. Ducousso, A. Kremer, 1994: Genetic, Morphological, Ecological and phenological Differentiation between Quercus petreae (Matt.) Liebel. and Quercus robur L. in a mixed Stand of Northwest of France, Silvae Genetica, 44(1): 1-10.

- Baliuckas, V., T. Lagerström, G. Eriksson, 2001: Within population variation in juvenile growth rhythm and growth in Quercus robur L. and Fagus sylvatica L., Forest Genetics, 8: 259-270.

- Basler, D., C. Körner, 2012: Photoperiod sensitivity of bud burst in 14 temperate forest tree species,Agricultural and Forest Meteorology, 165: 73-81.

- Billington, H.L., J. Pelham, 1991: Genetic variation in the date of leaf unfolding in Scottish birch populations: implications for climate change,Functional Ecology, 5: 403-409.

- Bonhomme, R., 2000: Bases and limits to using 'degree.day' units,European Journal of Agronomy, 13: 1-10.

- Caffarra, A., A. Donnelly, I. Chuine, 2011: Modeling the timing of Betula pubescens budburst. II. Integrating complex effects of photoperiod into process-based models, Climate Research,46(2): 159-170.

- Cannell, M.G.R., J.P. Palutikof, T. Sparks, 1999: Indicators of climate change in the Uk. London, United Kingdom.

- Cannell, M.G.R., R.I. Smith, 1983: Thermal time, chill days and prediction of budburst in Picea sitchensis. Journal of Applied Ecology, 20: 951-963.

- Cecich, R.A., 1997: The continuum between flowers and acorns. Diversity and Adaptation in Oak Species. Proceedings of the Second Meeting of Working Party 2.0.8.05, Genetics of Quercus, of the InternationalUnion of Forest Research Organizations, Pennsylvania State University (University Park, USA), October 12-17: 220-234.
- Chassagneux, P., E. Choisnel, 1986: Modélisation de Ièvaporation globale d'un couvert forestier. (I) Principes physiques et description de modèle,Annals of Forest Science, 43: 505-520.

- Chmura, D.J., R. Rožkowski, 2002: Variability of Beech Provenances in Spring and Autumn Phenology,Silvae Genetica, 51: 2-3.

- Chuine, I., 2000: A unified model for budburst of trees,Journal of Theoretical Biology, 207(3): 337-347.

- Chuine, I., J. Belmonte, A. Mignot, 2000: A modelling analysis of the genetic variation of phenology between tree populations, Journal of Ecology, 88: 561-570.

- Chuine, I., E.G. Beaubien,2001: Phenology is a major determinant of tree species range,Ecology Letter, 4: 500-510.

- Chuine, I., K. Kramer, H. Hanninen,2003: Plant development models. In. Schwartz M (ed). Phenology: An Integrative Environmental Science, Springer, New York, p. 217-235.

- Chuine, I., X. Morin, H. Bugmann, 2010: Warming, photoperiods, and tree phenology, Science, 329(5989): 277-278.

- Dantec, C.F., Y. Vitasse, M. Bonhomme, J.M. Louvet, A. Kremer, S. Delzon, 2014: Chilling and heat requirements for leaf unfolding in European beech and sessile oak populations at the southern limit of their distribution range, International Journal of Biometeorology, 58(9): 1853-1864.

- Davi, H., M. Gillmann, T. Ibanez, M. Cailleret, A. Bontemps ,B. Fady, F. Léfevre, 2011: Diversity of leaf unfolding dynamics among tree species: New insights from a study along an altitudinal gradient. Agricultural and Forest Meteorology, 151: 15041513.

- Davis, C.S., 2002: Statistical Methods for the Analysis of Repeated Measurements. Springer, New York, 416 pp.

- Delpierre, N., K. Soudani, F. Francois, B. Köstner, J.Y. Pontailler, M. Aubinet et al., 2009: Exceptional carbon uptake in European forests during the warm spring of 2007: a data-model analysis, Global Change Biology, 15(6): 1455-1474.

- Derory, J., P. Leger, V. Garcia, J. Schaeffer, M.T. Hauser, F. Salin et al., 2006: Transcriptome analysis of bud burst in sessile oak (Quercus petraea L.), New Phytology, 170: 723-738.

- DHMZ Državni hidrometeorološki zavod Republike Hrvatske.

- Dobrowolska, D., S. Hein, A. Oosterbaan, S. Wagner, J. Clark,J.P. Skovsgaard, 2011: A review of European ash (Fraxinus excelsior L.): implications for silviculture, Forestry, 84(2): 13-3148.

- Fu, Y.H., M. Campioli,G. Deckmyn, I.A. Janssens, 2013: Sensitivity of leaf unfolding to experimental warming in three temperate tree species,Agricultural and Forest Meteorology,181: 125132.

- Fu, Y., M. Campioli, G. Deckmyn, I.A. Janssens, 2012: The impact of winter and spring temperatures on temperate tree budburst dates: results from an experimenbtal climate manipulation, PloS ONE,7(10): e47324.

- Garber, M.P., 1983: Effects of chilling and photoperiod on dormancy release of container-grown loblolly pine seedlings,Canadian Journal of Forest Research, 13: 1265-1270.

- García-Mozo, H., P.J. Hidalgo, C. Galán, M.T. Gómez-Casero, E. Domínguez, 2001: Catkin frost damage in Mediterranean corkoak (Quercus suber L.). Israel Journal of Plant Science, 49: 41-47.

- Gömöry, D.,L. Paule,2011: Trade-off between height growth and spring flushing in common beech (Fagus sylvatica L.),Annals of Forest Science, 68: 975-984.

- Guak, S., D.M. Olsyzk, L.H. Fuchigami, D.T. Tingey, 1998: Effects of elevated $\mathrm{CO}_{2}$ and temperature on cold hardiness and 
spring bud burst and growth in Douglas-fir (Pseudotsuga menziessi), Tree Physiology, 18: 671-679.

- Hänninen, H., 1990: Modelling bud dormancy release in trees from cool and temperate regions, Acta Forestalia Fennica, 213: 1-47.

- Hänninen, H., K. Kramer, 2007: A framework for modelling the annual cycle of trees in boreal and temperate regions, Silva Fennica, 41(1): 167-205.

- Heide, O., 1993: Daylength and thermal time responses of budburst during dormancy release in some northern decidious trees, Physiologia Plantarum, 88(4): 531-540.

- Hollister, R.D., P.J. Webber, C. Bay, 2005: Plant response to temperature in northern Alaska: implications for predicting vegetation change, Ecology, 86: 1562-1570.

- Hunter, A.F., M.J. Lechowicz,1992: Predicting the timing of budburst in temperate trees, Journal of Applied Ecology, 29: 597-604.

- Hunter, M.D., 1992: A variable insect plant interaction: The relationship between tree bud burst phenology and population levels of insect herbivores among trees, Ecological Entomology, 16: 91-95.

- Jazbec, A., K. Šegotić, M. Ivanković, H. Marjanović, S. Perić, 2007: Ranking of European beech provenances in Croatia using statistical analysis and analytical hierarchy process, Forestry, 80: 151-162.

- Kajba, D., N. Pavičić, S. Bogdan, I. Katičić, 2008: Pomotechnical treatments in the broadleave clonal seed orchard, Seed Orchard Conference, Umeå (Sweden), September 26-28: 95-103.

- Kasprzyk, I., 2009: Forecasting the start of Quercus pollen season using several methods - the evaluation of their efficiency, International Journal of Biometeorology, 53: 345-353.

- Katičić, I., S. Bogdan, K. Sever, Z. Šatović, D. Kajba, 2010: Genetic structure and variability of phenological forms of pedunculate oak (Quercus robur L.) from clonal seed orchards in Croatia. Forest ecosystem genomics and adaptation; Vincente B, Neate P (eds), Bioversity International and INIA, $181 \mathrm{pp}$.

- Kilpelainen, A., H. Peltola, I. Rouvinen, S. Kellomaki, 2006: Dynamics of daily height growth in Scots pine trees at elevated temperature and $\mathrm{CO}_{2}$, Trees-Structure and Function, 20: 162-7.

- Klepac, D., 2000: The biggest forest of pedunculate oak in Croatia: Spačva. Hrvatske šume, HAZU Vinkovci, 117 pp.

- Körner, C., D. Basler, 2010: Phenology under global warming, Science, 327(5972): 1461-1462.

- Kramer, K., 1994: Selecting a model to predict the onset of growth of Fagus sylvatica, Journal of Applied Ecology, 31: 172-181.

- Kramer, K., I. Leinonen, D. Loustau, 2000: The importance of phenology for the evaluation of impact of climate change on growth of boreal temperate and Mediterranean forests ecosystems: an overview,International Journal of Biometeorology, 44: 67-75.

- McMaster, G.S., W.W. Wilhelm, 1997: Growing degree-days: one equation, two interpretations, Agricultural and Forest Meteorology, 87: 291-300.

- Mátyás, V., 1967: Tölgy makk - termesztes. In: A tölgyek; Keresztesi B (ed), Akadémiai kiadó, Budapest, 204-237.

- Menzel, A., 2000: Trends in phenological phases in Europe between 1951 and 1996, International Journal of Biometeorology, 44: 76-81.

- Menzel, A., 2002: Phenology: its importance to the global change community, Climate Change, 54: 379-385.
- Menzel, A., N. Estrella, P. Fabian, 2001: Spatial and temporal variability of the phenological seasons in Germany from 1951 to 1996, Global Change Biology, 7: 657-666.

- Morin, X., J. Roy, L. Sonie, I. Chuine, 2010: Changes in leaf phenology of three European oak species in response to experimental climate change, New Phytology, 186: 900-910.

- Murray, M.B., M.G.R. Cannell, R.I. Smith, 1989: Date of budburst of fifteen tree species in Britain following climatic warming, Journal of Applied Ecology, 26: 693-700.

- Nizinski, J.J., B. Saugier, 1988: A model of leaf budding and development for a mature Quercus forest, Journal of Applied Ecology, 25: 643-652.

- Nienstaedi, H., 1966: Dormancy and dormancy release in white spruce, Forest Science, 12: 374-384.

- Perić, S., J. Gračan, B. Dalbelo-Bašić, 2000: Flushing variability of pedunculate oak (Quercus robur L.) in the provenance experiment in Croatia, Glasnik za šumske pokuse, 37: 395-412.

- Phillimore, A.B., K. Proios, N. O’Mahony, R. Bernard, A.M. Lord, S. Atkinson et al., 2013: Inferring local processes from macro-scale phenological pattern: a comparison of two methods, Journal of Ecology, 101: 774-783.

- Repo, T., H. Hanninen,S. Kellomaki, 1996: The effects of longterm elevation of air temperature and $\mathrm{CO}_{2}$ on the frost hardiness of Scots pine, Plant, Cell\& Environment, 19: 209-216.

- Rousi, M., J. Pusenius, 2005: Variations in phenology and growth of European white birch (Betula pendula) clones, Tree Physiology, 25: 201-210.

- Sarvas, R., 1972: Investigations on the annual cycle of development on forest trees active period,Communicationes Instituti Forestalis Fenniae, 76: 110.

- Sarvas, R., 1974: Investigations on the annual cycle of development of forest trees. Autumn dormancy and winter dormancy,Communicationes Instituti Forestalis Fenniae,84: 101.

- Sanz-Perez, V., P. Castro-Diez, F. Valladares,2009: Differential and interactive effects of temperature and photoperiod on budburst and carbon reserves in two co-occurring Mediterranean oaks, Plant Biology, 11: 142-151.

- Schütte, F., 1957: Untersuchungen über die Populationsdynamik des Eichenwicklers Tortrix viridiana L. Z. Angew, Entomology, 40: 1-36.

- Schwartz, M., 2003: Phenology: An integrative environmental science, Springer, New York, 610 pp.

- Snyder, R.L., 1985: Hand calculating degree days, Agricultural and Forest Meterology, 35: 353-358.

- Sokal, R., F.J. Rohlf, 1995: Biometry: the principles and practice of statistics in biological research, W. H. Freeman and Company, New York, 880 pp.

- Sparks, T.H.,P.D. Carey, 1995: The responses of species to climate over two centuries: an analysis of the Marsham phenological record, 1736-1947, Journal of Animal Ecology, 83: 321329.

- StatSoft, Inc. 2013 STATISTICA (data analysis software system) version 11.0

- Stojković, M., 1991: Varijabilnost i nasljednost listanja hrasta lužnjaka (Quercus robur L.), Glasnik za šumske pokuse, 27: 227259.

- Tikkanen, O.P., R. Julkunen-Tiltto, 2003: Phenological variation as protection against defoliating insects: the case of Quercus robur and Operophtera brumata, Oecologia, 136: 244-251. 
- Vitasse, Y., C.C. Bresson, A. Kremer, R. Michalet, S. Delzon, 2010: Quantifying phenological plasticity to temperature in two temperate tree species, Functional Ecology, 24: 1211-1218.

- von Wuehlisch, G., D. Krusche, H.J. Muhs, 1995: Variation in temperature sum requirement for flushing of beech provenances, Silvae Genetica, 44: 343-346.

- Wareing, P.F., 1953: Growth studies in woody species V. Photoperiodism in dormant buds of Fagus sylvatica, Physiologia Plantarum, 6(4): 692-706.

- Wesolowski, T., P. Rowiński, 2006: Tree defoliation by winter moth Operophtera brumata L. during an outbreak affected by structure of forest landscape,ForestEcology and Management, 221: 299-305.

- Wesolowski, T., P. Rowiński, 2008: Late leaf development in penduculate oak (Quercus robur): An antiherbivore defence, Scandinavian Journal of Forest Research, 23: 386-394.

- Wolgast, L.J., 1972: Oak mast production in scrub oak (Quercus ilicifolia) on the coastal plain in New Yersey, Doctoral theisis, Rutgers University, New Brunswick.

- Worral, J., 1983: Temperature bud-burst relationships in Amabi$l i s$ and Subalpine fir provenance tests replicated at different elevations, Silvae Genetica, 32: 203-209.

\section{Sažetak}

Biološki mehanizam listanja pod izravnim je utjecajem okolišnih čimbenika. Razvijeni su mnogi modeli i objavljene različite studije s ciljem što boljeg opisa pojedinog biološkog mehanizma fenoloških svojstava, a koji su izloženi upravo okolišnim čimbenicima tijekom svoga života. Temperatura je neminovno jedan od najbitnijih čimbenika za pokretanje mnogih procesa u biljci i upravo je ona okosnica većine izrađenih modela. Growing Degree Days model se temelji na minimalnim i maksimalnim temperaturama, te na baznoj temperaturi, odosno temperaturnom pragu iznad kojeg se aktiviraju procesi u biljci.

Istraživanja u ovome radu temelje se na desetogodišnjem monitoringu početka listanja hrasta lužnjaka u klonskoj sjemenskoj plantaži koja sadrži ukupno 53 genotipa. Cilj je bio utvrditi ponašanje svojstva listanja te implementirati dobivene rezultate $\mathrm{u}$ GDD model. S obzirom da je već poznato da hrast lužnjak ima svoje tri fenološke forme listanja (rane, intermedijarne i kasne), bilo je potrebno dokazati da se te tri grupe jasno diferenciraju i po temperaturnim sumama, odnosno GDD-u. Razdoblje monitoringa u svakoj godini bilo je oko 130/131 dan, odnosno od 1.siječnja do 10.svibnja. Izračunom GDDa i povezivanjem tog modela s dobivenim vrijednostima početka listanja, iskazala se jasna segregacija na već spomenute tri forme. Svakoj fenološkoj grupi, dodijeljen je interval vrijednosti temperaturnih suma koje su potrebne da bi ta fenološka forma započela s listanjem. S obzirom na godišnje vrijednosti temperaturnih suma koje su potrebne pojedinoj formi da krene s listanjem, evidentno je bilo da vrijednosti značajno variraju kroz godine, i to za kompletno promatrano razdoblje. Upravo to variranje onemogućava da se putem GDD modela izradi simulacijski model, koji bi mogao, uz određena manja odstupanja, predvidjeti početak listanja za iduće razdoblje. Važnost predviđanja nije jednostrana, naprotiv, cijeli je niz sinergijskih čimbenika koji su izravno ili neizravno vezani za početak listanja pojedinih vrsta šumskog drveća, među kojima možemo spomenuti stadijni razvoj entomofagnih i fitopatogenih štetnika, koji su svojom biologijom usko vezani za biologiju određene vrste drveća.

S obzirom na izraženo variranje vrijednosti temperaturnih suma, po fenološkim formama, u istraživanja su uključeni i drugi okolišni čimbenici, kao što su količina oborina (mm), insolacija i broj dana. Cilj je bio ispitati kako se ova tri čimbenika ponašaju s obzirom na kretanje GDD vrijednosti, odnosno koji od ispitivanih čimbenika je preciznija poveznica za svojstvo početka listanja. Statističkom obradom podataka, jasno su i s visokim postotkom isključeni količina oborina i broj dana kao čimbenici koji definitivno ne utječu ili utječu s jako malim učešćem na kretanje vrijednosti GDD-a. Insolacija se iskazala kao čimbenik koji s najvećim udjelom sudjeluje u kretanju GDD vrijednosti i to za ranu fenološku formu sa $74,1 \%$, za intermedijarnu formu sa $90,6 \%$, te za fenološku formu kasnog listanja sa $78,7 \%$.

KLJUČNE RIJEČI: fenologija listanja, promjena klime, GDD, klimatološki parametri, hladne temperaturne jedinice. 